\title{
UNLOCKING DOORS: DECOLONISING THE DESIGN OF AN ART EXHIBITION IN ZIMBABWE
}

Pamela Zigomo

Department of Marketing, Events and Tourism, University of Greenwich, London, UK Richard Hull

Institute of Creative and Cultural Entrepreneurship, Goldsmiths University of London, London, UK

Corresponding author: Pamela Zigomo, Senior Lecturer, University of Greenwich, Greenwich Campus, Old Royal Naval College, Park Row, London SE10 9LS, UK; Email: p.zigomo@greenwich.ac.uk

Richard Hull, Ph.D., Director MA Social Entrepreneurship, Institute of Creative and Cultural Entrepreneurship, Goldsmiths University of London, New Cross, London SE14 6NW, UK; Email: $\underline{\text { r.hull@gold.ac.uk }}$ 


\begin{abstract}
Participatory event design opens up opportunities for the sustainable transformation of a community and can therefore make a valuable contribution to the field of critical event studies. This paper discusses the findings from a participatory action research project developed with a community of visual artists in Zimbabwe. The project explored how participatory event design processes could be applied to the co-creation of an art exhibition which would be used as a platform to challenge the oppressive environment Zimbabwean visual artists are working in. The design of special events in the third sector is usually reliant on the voice of the specialist event designer or organiser who is commissioned by the funding or lead agency to develop an event intervention using risk averse and time efficient methods. This, unfortunately, can result in in the community of interest having a marginalised role in the proceedings and thus they lose a muchneeded connection with the event intervention and are not committed to sustaining the desired change. We argue that there is an opportunity for events professionals to increase their skills and develop emancipatory approaches that will decolonise established event design processes and contribute to the sustainable transformation of marginalised communities.
\end{abstract}

Keywords: Participatory event design, Critical pedagogy, Decolonisation, Zimbabwe 


\section{UNLOCKING DOORS: DECOLONISING THE DESIGN OF AN ART EXHIBITION IN ZIMBABWE INTRODUCTION}

Critical Event Studies (CES) examines the political, economic, social and cultural structures that frame event production and the resultant impacts on communities of interest (Lamond \& Platt, 2016). CES applies critical theories to understand how events are created and managed, rather than the more usual established focus on operational and management aspects. This project has applied Paulo Freire's critical pedagogy (Freire, 1996) and post-colonial theory (Said, 2003; Thiong'o, 1986; Fanon, 1963) to explore how participatory event design can be used as a tool for social change in the Third Sector. The project was developed by the principal author for her $\mathrm{PhD}$ research project which explores how arts events can be designed to effect social change. The researcher partnered with a group of Zimbabwean visual artists keen to design an art exhibition event that would give them direct access to local and international networks to improve their livelihoods. As the project is still ongoing, this paper focuses on the emergent findings.

Loomba (2005) posits that communities within a societal structure will behave in a certain way based on beliefs and ideologies that inform their thinking. The community of Zimbabwean visual artists participating in this research project were working within a societal structure which was strongly influenced by the political, economic and cultural context of the country. The visual arts sector in Zimbabwe has historically been developed around systems of patronage (Chikukwa, 2015; Sibanda, 2015). African artists are denied access to the economic networks that impact their livelihoods because gallerists (gallery owners) are reluctant to share their contacts and government uses censorship tactics to control the artistic content produced. Art 
exhibition events are designed in controlled spaces by gallery owners and curators who have the power to bestow value on artistic product. Accordingly, exhibition design becomes a mystical process which marginalises the artists as they are silenced. Thus, post-colonial theory created a space for us to examine the inherent power and relational structures informing these established event design processes.

Events in the Third Sector are developed to address social problems but there is little evidence these events have actually achieved a sustainable change. We thus need new ways of examining established event design processes to identify potential areas that reinforce oppressive structures. We suggest here that the lens of postcolonial theory, based on the works of Edward Said (2003), Ngugi wa Thiong'o (1986) and Frantz Fanon (1963) is one such new perspective upon the social impact of Third Sector events.

Space - access to it and organisation of spaces for interaction - is a critical theme in postcolonial studies. Fanon (1963) explains how colonisers set up what he terms a 'manichean' worldview (a world divided in two) where social structures and physical spaces were compartmentalised as a means of control. When spaces became restricted the colonised lost a sense of self (Fanon, 1963). This manichean world establishes implicit power hierarchies that divide and ultimately weaken the colonised community, making it easier to control (Fanon, 1963). Colonial structures were established that enabled one group to take a higher position and monitor and manage the lower group (Escobar, 1995). It is important to understand how communities engage with different spaces; even in the post-colonial era some spaces are still considered inaccessible by the local communities. Thiong'o (1986) notes this in his account of his project to decolonise Kenyan cultural spaces, specifically the local community theatres. The cultural elite who rely on hegemonic systems that manage and control these spaces are usually 
given more access to these spaces, so they end up monopolising the spaces as they have more power over them (Thiong'o, 1986). This automatically ostracizes the local communities who cannot relate to these spaces and thus do not engage. These two worlds are always presented as opposites - one is mystical, desirable, plentiful and appears to be indestructible while the other is unattractive, cramped, and appears to be excessively lacking in resources (Fanon, 1963).

The event design process can also be said to set up a compartmentalised worldview through the monologic or didactic processes (Freire, 1996) that are adopted by those that take on the specialist role of event designer. When event designers are commissioned to design a special event with a social mission, the design process adopts an established business format guided by objectives focussed on designing an experience that meets the desired outcomes set by the funding organisation or commissioning agency (Richards, Marques, \& Mein, 2015). In a commercial environment established approaches to event design are appropriate but in the Third Sector a change in approach is required (Olberding, 2017).

Event design takes place in remote office locations that are not always accessible to the communities of interest. Thus, the process of event design can appear to be mystical and intimidating for communities of interest who then believe they have nothing of value to contribute to the process of transforming their societal structure. The community of interest has nothing to establish or validate their identity in the event process and has no space or responsibilities in the event space which is not really theirs (Clarke \& Jepson, 2011). Thus, they are not represented and cannot ensure the correct stories are being told on their behalf at the event. If communities of interest feel the space is not really theirs then they begin to question why they should engage or feel committed to the transformation intervention and apathy sets in. 
There is no motivation to see through the change required. This leads to what Freire (1996) calls 'a culture of silence'.

\section{Participatory Development}

Third Sector interventions with a social aim are increasingly borrowing principles from the field of Participatory Development, which emerged in the international development arena in the 1980's and 1990's in response to the call for more people-centred, empowering approaches (Mohan, 2001). Prior to this, authors like Chambers (1994) and Escobar (1995), highlighted the oppressive nature of international development projects which usually adopted an oppressive vertical and binary view, reminiscent of the colonial era. A top-down, project-based approach to community development was regularly applied, where outsider experts (the uppers) represented by government agencies or non-governmental organisations (NGO's) would implement interventions focused on extracting knowledge from communities of interest (the lowers), to provide knowledge for people outside of the community (Chambers, 1994). Chambers developed methods and applications for participatory approaches through the practice of Participatory Rural Appraisal (Chambers, 1994). He drew on Freire's critical pedagogy to examine new strategies to deal with the binary relationships set up in the development process and recommend relationships which adopted more of a bottom-up approach, focusing on the community (the lowers) actively taking part in their own research investigations and analysis so as to change relationships with NGO's (the uppers). Chambers (2006) refers to the framework developed by VeneKlasen \& Miller (2002) to assert that participatory development interventions focus on supporting marginalised communities to gain power within (self-confidence) and power with (collective power) to change relationships with those that have the power over (the uppers who have the power). 


\section{Participatory Design}

Another very relevant form of community engagement is Participatory Design, introduced at a 1971 conference 'Design Participation' where new thinking around design was prompted by the growth of community action and social movements fighting for democracy (Lee, 2008). Participatory Design techniques aim at creating context awareness by eliciting emotional response from participants (Sanders \& Stappers, 2008). Whilst a designer always has a view on what is the context, this is usually a personal view based on their experiences, whereas research with real users can provide a richer, less subjective and more dependable view on the situations in which products will actually be used. Krippendorff predicted in 2011 that design of the future will be more of a democratic process, not top-down. Interactivity and participation would be key as the design process would need to acknowledge 'heterarchy' rather than 'hierarchy' to be effective. A key point in Krippendorff's discussion is the death of the expert and ultimately the loss of control and power for the designer. Krippendorff (2011) highlights the importance of developing social networks, because effective design artefacts now have to be created within the political, economic and sociological dimension within which designers are now working.

\section{Participatory Event Design}

Although there are user-led and capacity building approaches for public-sector events the sector needs better ways to measure their impact, specifically in connection with their contribution to community practice and changing behaviour (O'Sullivan, 2012). Studies of participatory event production and planning in relation to community festival events advocate community involvement but suggest there is little agreement regarding the optimum level of participation for community events (Clarke \& Jepson, 2011; Jepson, Clarke, \& Ragsdell, 2013; 
2014; Finkel \& Sang, 2016). Authors have also noted that the societal structures of each community are complex and differ, thus the social, cultural, economic and political contexts must be taken into account in planning participation (Hung, Sirakaya-Turk, \& Ingram, 2011; Jepson et al., 2013). This appears to align more with the evolution in thinking on the need for democracy, dialogue and empowerment in areas of participatory design and community development (Chambers, 2006; Krippendorff, 2011).

Although there is no specific literature on community participation in relation to event design, there are two approaches to community participation in leisure and tourism studies. First, maximise participation, which involves full immersion by the community in the planning process where the community have power over the decision-making process (Simmons, 1994; Cole, 2006; Lekaota, 2015). Second, more limited/measured participation, based on the premise that effective participation in the planning process requires a level of skill and knowledge (Taylor, 1995; Tosun \& Timothy, 2003). Studies discussing community participation also raise the question of appropriate and effective levels of participation in order to establish a typology of participation. Both the fields of product design and event studies make reference to Arnstein's Ladder of Participation (Arnstein, 1969), developed in relation to observations of public planning structures in America and which makes useful recommendations applicable to the set up of participatory event design processes.

\section{Risks of Participatory Approaches}

There are risks to adopting a participatory approach. Most significant is that the findings will be considered too subjective and too focused on a specific group thus limiting the contribution of the research findings (Kemmis \& McTaggart, 2000; Leavy, 2017). This risk can be mitigated through the use of validation panels and discussion with other stakeholders from 
this social structure (Chambers, 2006; Mohan, 2001). Critiques of participatory development approaches (Mohan, 2001; Parfitt, 2004) highlight the risks of adopting a binary approach as it reinforces practices of othering (Said, 2003) and could set up the oppressive manichean structures (Fanon, 1963) that the approach seeks to eliminate. In instances where the approach is seen as a means to gain legitimacy or funding, it can result in tokenism or manipulation of communities (Mohan, 2001). There are also key ethical issues relating to power relationships. Hung et al (2011) proposed that equity can only be achieved through power- sharing but noted that the redistribution of power sharing in stakeholder coalitions is rare. There are usually power brokers - those who hold direct power over the event and its development and there are also independent centres of power which have limited democracy (Clarke \& Jepson, 2011; Rojek, 2013; Finkel \& Sang, 2016).

\section{Zimbabwe}

Pursuing a career as a visual artist in Zimbabwe is not viewed as a wise choice if one wants to earn a sustainable livelihood there. The political decisions made in the past have had a significant impact on the development of the sector. From colonial times to post-independence, creative and cultural practice has been controlled and carefully managed with the aim of subduing and censoring any form of creative expression that might upset the status quo (Vambe, 2000). A limited understanding of how to support and develop the sector amongst policy makers has also resulted in the remit for the cultural and creative industries sector being split among 11 ministries. The sector has suffered from a history of marginal investment by government with the majority of financial support for the development of the sector coming from international donor agencies (Mukanga, 2011). 
Surveys conducted by Nhimbe Trust and Zimstats in 2012 revealed that the sector appears to be made up of individuals and small enterprises. The highest returns on trade transactions of creative product per dollar are made by middle men. Middle men are individuals that approach artists with promises of lucrative deals, at times they acquire artwork at a discount with the promise of generating further revenue for the artists at a later time when they sell on the work to international collectors. This reliance on middle men indicates weak entrepreneurial skills within the sector. In 2011, the Labour Force and Child Labour survey revealed that, of the 5.4 million employed in the country, 22,000 were employed in the cultural industries sector. Most cultural practitioners in the country focus on international markets (Mari, 2011). Practitioners are also unable to rely on their cultural products as their primary source of income and thus have to find other sources of income to eke out a living. There is a disconnect between practitioners, local markets and policymakers, practitioners find it challenging to engage with policymakers as most work in isolation and find it hard to form a critical mass to address these challenges.

\section{METHOD}

This research project firstly sought to understand how participatory event design processes could be effectively adopted to develop events with a social mission and secondly to understand the experiences of the co-designers taking part in the participatory process. A participatory action research (PAR) approach was adopted for this project. PAR is a method that creates a space for researchers and research participants to undertake a collaborative analysis of real life problems (Kindon, Pain \& Kesby, 2007). PAR acknowledges and respects the diverse sources of knowledge within a community (Creswell, 2003). It prompts all participants involved to reflect on their findings and experiences and then decide on the most appropriate action to 
address the issues, thus removing the mindset that human agency is only a right of the project expert (Kesby \& Gwanzura-Ottemoller, 2007). Therefore, the researcher must take the opportunity to listen carefully and ask broad and general questions that enables them to build a rich picture that gives a deeper understanding of a particular situation.

The questions that directed the development of the project were:

- How do we design events for the Third Sector that will effect social change?

- Can we prevent oppressive conditions that stifle transformation?

The PAR approach is practical and collaborative as it is inquiry that is completed with others rather than 'on' or 'to' others (Kindon, Pain and Kesby, 2007). Thus, it supports critical pedagogy's call for dialogic and democratic processes (Freire, 1996) and the removal of structures where the researcher sets themselves in a separate or higher position of power which reinforces the 'othering' of the community of interest as discussed in postcolonial studies (Said, 2003; Mertens, 2010; Smith, 2012). PAR is emancipatory, the approach is focused on supporting individuals as they free themselves from limiting constraints that are inherent in the power relationships that are at play in their complex societal structures and day-to day settings (Kemmis \& McTaggart, 2000). The approach encourages researchers to avoid situations where they offer what Freire (1996) terms 'false liberation'. The approach allows for regular and progressive dialogue following periods of critical reflection with the aim of bringing about change in practices. Thus, at the end of a participatory project, both researchers and participants can advance an action agenda for change.

\section{Finding Research Partners}

As noted earlier, the principal author developed the project in the course of her $\mathrm{PhD}$ studies. Being Zimbabwean, she sought to develop a self-funded project that would enable her to 
work in a country context she was familiar with. Contact was made with an informal group of 25 visual artists living and working in Harare who regularly communicated as a social media group, using the social network platform WhatsApp. Preliminary primary and secondary research was conducted to gain a deeper understanding of the research context and day-to-day challenges the research participants were facing. This exploratory research was a combination of in-depth interviews with visual artists, gallerists and policymakers and a review of the published reports and minutes of plenary discussions from key research projects and conferences convened to discuss the state of Zimbabwe's cultural sector. The initial study - a combination of secondary research and primary interviews - indicated that it would not be possible to call together a larger nationwide grouping to be involved in the research. The disparate power levels that exist within this social structure would make it too challenging. As a result, the researcher focused on working with a community of visual artists. Of the 25 artists that were originally approached, 17 artists decided to take part and eight opted out. Table 1. provides an overview of the participant demographics.

\section{$<<$ TABLE 1 HERE $>>>$}

\section{Collaboration Strategy}

The collaboration strategy included clarifying roles and expectations; there would be a research-facilitator - (the PhD researcher who was also an event practitioner) who would offer their skills and source the resources the group would require for their event design activities. It was clearly stated at the beginning and throughout the life of the project that the researchfacilitator was not in a higher power position and would facilitate the decision making for the entire team and data collection and analysis. All visual artists participating were co-researchers and all group members would work together in the design activities as well come together to 
reflect on the project and discuss learning points. Any action based social change project where participation, democracy and dialogue are key brings with it the fact that some form of power must be re-distributed (Parfitt, 2004; Dagron, 2009). This can be problematic therefore it was important to warn participants that there could be repercussions to their taking part. To prepare for this some time was taken at the beginning of the project to carefully set expectations and negotiate how the group would work and agree a set of project values that the group wanted to adopt.

The participatory design activities took place in a series of 3 workshops held over a twelve-month period. Two online spaces for group working and communications were set up. Slack (Slack.com), a team -working application and WhatsApp (Whatsapp.com), were used. Slack was useful for the group to use in setting up the project and negotiating project goals and prioritising areas to focus on. Slack was also useful during the group reflection and conscientisation phases as well as the initial event concept development discussions. WhatsApp was used after the first project phase to communicate updates on resourcing and planning the event and maintaining the new relationships that were developed in the design phase.

\section{DATA COLLECTION AND ANALYSIS}

Data collected included transcripts from workshop discussions and transcripts from discussions on Slack and WhatsApp. Some of the group discussions and reflections included sharing of visual images representative of key issues and these images were also collected. The research-facilitator systematically reviewed all the transcripts and created codes, using a combination of both emergent and pre-set codes. For example, two of the pre-set code were 'challenges' and 'space' and two emergent codes were 'confidence' and 'risks'. The second phase of data analysis was carried at an evaluation and reflection workshop where the group 
came together and discussed their experiences and recommendations of how to improve the participatory design process the next time. As recommended by Finkel \& Sang (2016), the research-facilitator also referred back to discussions in the design workshop and asked group members to make sense and construct meaning through reflection and further dialogue.

\section{FINDINGS AND DISCUSSION}

\section{Motivations to Take Part}

The group initially went through a process of sharing their priorities and vision of success for the project. The range of suggestions can be seen in the conversation thread below, ultimately the group agreed that they wanted to form a critical mass so that they could access local and international markets.

CR4: I would like to learn other artists' views, gain market entry that accommodates our artworks, exhibit artworks online and in galleries.

CR8: To find a stable market for our work and to get to a level of expressing our views freely without fear or influence from people in power. We want to be the voice of the voiceless through our creative works. I wish the group will not back down but instead solidify to accomplish our goals together standing for ourselves.

CR10: We need to look out for each other, this group is the beginning of something that could change not only our lives, but the art scene in Zimbabwe. Let's not look to outsiders to help us, let's put our minds together, then as one force, we will be able to get funding for whatever projects we desire as a team. It's easier to get group funding than individual.

Spaaij \& Jeanes (2013) remind us critical pedagogy assumes that each human being is capable of looking critically at their world in a dialogical encounter with others. This was evident as the co- 
researchers were able to map out the factors contributing to the structural inequalities they faced as well as areas where they could intervene to improve their situation.

CR12: They are attaching us to something and they keep saying 'let us attach them this year to this ministry', because they don't understand us

CR13: They don't understand us, actually they are inconsistent.

CR10: But ... who's responsibility is it?...to get them to understand us?... How will they know?

CR2 \& CR3: Ours!...

CR14: It's the artist... us the artist... if we are together that's when they can hear us, if we are individual they cannot get it and that's the challenge of visual artists

Spending time sharing the challenges they were facing helped the group to bond and develop a sense of agency for the participatory design workshop.

$\boldsymbol{R F}$ : How do we move forward and refine our focus to ensure the big event addresses some of these key issues?

CR13: We now want everyone's contribution, maybe to set a meeting to discuss face to face and then we vote from these topics, this way we can come up with a clear focus.

\section{Space and Access for Design}

The choice of space for their design activity was a significant factor for the participants and one where their opinions differed to the research-facilitator. The research-facilitator believed that using the established spaces for event design such as galleries and cultural venues of national standing, could have the positive impact of de-mystifying these cultural spaces and raise levels of confidence amongst the participants as they moved out of the borderlands and entered 
the sacred spaces (Nelson, 2009). Three iconic cultural venues were approached and the hire fees for these spaces were outside of the agreed budget and thus the final location selected was a meeting room in a Methodist Church in the town centre, a block away from the national gallery. The research-facilitator was surprised to learn the group's perception of the design space:

CR7: If we were at the national gallery I wouldn't be that comfortable like the way I am in this space. In this space I feel we are all equal

CR1: Yah...because maybe the curator or someone high up who knows what we as artists are going through hears what we are talking about... they might get ideas...of what to do next from what we are talking about...they might eavesdrop and they hear what we are saying and they take it to someone else ...so they leak our confidential information CR10: .... at the start of this project we wanted this to be a project for freedom, where we could do what we wanted by ourselves, without the galleries, so in here there is more of a feeling of freedom that wouldn't have been there if we had been in the galleries, here we feel we are in charge.

CR13: Yah if we had ended up in those places you would find they take over the conversation and it's only going in one direction...

CR4: because we are afraid to speak...what's the saying...walls have ears... and also eyes.... (room agrees) ....

Some authors have recommended that authentic PAR and participatory design projects should involve all stakeholders or representatives of each stakeholder group (Kemmis and McTaggart, 2000; Sanders and Stappers, 2008; Leavy, 2017). This approach would not have been appropriate for this group which was operating in a context of mistrust and fear. It was evident how important it was to use safe, open and neutral spaces for the participatory event design activities. 


\section{Participants' Relationship with Established Design Spaces}

The group discussed their encounters with gallerists when trying to get involved in previous exhibition events. They noted that their relationship with the gallerists was tied to their need to access the event spaces so that they could gain access to economic benefits they felt were only available once inside:

CR7: ...some of the gallery owners have skin like ours ... what will make him or her powerful is because he's got something you want and it's for them to show your work, so that's the only power they have and if he just says I don't like this you are powerless because you were thinking if I get inside there I will get to some level but if you are denied the opportunity then definitely the next thing you will be lacking is food, then you ask 'please, please can you even just put my work at the back of the gallery, because you need to at least be linked to that certain gallery

CR5: This is very true, you see many artists look as if they have no confidence or are not sure with what they are doing it's because we are used to working with the kind of people that harass us each and every time, they threaten us, so that sometimes when we come in with work they will tell us 'this is junk' and you won't ever make it to an exhibition.

CR1: At times you get told off... You are told, its rubbish....

CR13: It's a way of intimidating you

CR8: Some of them like to control what you create, they will only want you to create work that portrays the country as being bad when you want to create work that shows the good things about the country...

This conversation shed light on the historical relationships between artists and their mentors who ran the galleries in Zimbabwe (Sibanda, 2015). Artists could only access certain cultural spaces 
due to the patronage of the well-known gallerists and collectors, thus they maintained their silence in dealing with mentors or patrons even in situations where they knew they were being exploited - with the aim of gaining their economic independence (Chikukwa, 2015).

\section{Developing the Event Concept}

The project started at a time when there was nationwide frustration with the prevailing political and economic situation in the country. Civil servants had not been paid in the months prior and the cash crisis in the country was coming to a head, the governor of the Reserve Bank had just announced the introduction of the Bond Note (a parallel currency equivalent to the US dollar). Civil society and activist groups were also gaining critical mass and organising a series of nationwide protests and stay-aways or strikes, where all workers do not go to work as a form of protest. Group members were quick to share how the current situation was impacting them personally and suggested themes that were linked to their current experiences and focus on survival.

CR10: In light of what is happening in Zimbabwe right now, politically, we could decide to use this event to speak up as Zimbabweans looking to a brighter future. Themed 'a brighter tomorrow', or 'restoration' not so much focusing on politics but on hope that Zimbabwe will once again be all it was and more, almost like speaking into our future in a positive light. A lot of stakeholders will be interested in that one because everyone is looking forward to, more like anxious for positive change, to the extent of worldwide coverage if we do it well. That is how we can be a part of this revolution, by speaking using our craft but by being positive at the same time. 
The group came up with a list of 7 themes and then proceeded to reflect on and discuss those themes and their potential impact. The artists noted the challenges they might face and picked the one they felt most comfortable to fight.

CR15: Some of the work can show oppression and some work can show issues of human rights, because to talk about them (policy makers) directly will upset them as we have to also talk about their corruption

Group members finally decided on the theme 'Unlocking Doors', considering it safe enough to be interpreted widely and not be a direct or explicit political statement. The prevailing literature relating to event management has a tendency to advocate that the event concept be evaluated using filters that address the 3 aspects of finance, market expectations and operational capabilities (Bowdin, Allen, O’Toole, Harris, \& McDonnell, 2012; Bladen, Kennell, Abson, \& Wilde, 2017; Shone and Parry, 2013). We found that for the participatory design process here, the consideration of risk to the community of interest took precedence over all other feasibility criteria. This was understandable given the experiences artists had shared of being mistreated by gallerists in the past. The political and economic context also influenced the level of risk the artists were willing to take. The Zimbabwean government had responded to rising public unrest and criticism of the nation's leaders by implementing legislation such as the Public Order and Security Act and the Law and Order Maintenance Act. These laws were an effective form of coercion as they gave the police the power to prohibit or disperse public gatherings and restrict access to performance or event spaces classified as political events (Zenenga, 2008). The coresearchers were careful to consider each theme that had been proposed in light of how it could affect them in the long term. 
Having been restricted access to the event design spaces the co-researchers were keen to be transparent in the production of their exhibition event, they wanted to move away from closed spaces and wanted the event to be accessible to all.

CR13: Let's create something in the open that people can see as we develop it, let's not make it mystical because I realise that people like to say 'oh he went abroad' but when you return people won't know what you were doing and they are even afraid to go into a gallery to see what you were doing.

\section{Event Design Experts - the Role of the Exhibition Curator}

The issue of the curator was a sensitive point for the participants and it took a while for them to be comfortable enough to address it. The first time the need for a curator for the exhibition came up in discussion was during the design workshop, when one of the group members raised the question first as to when a curator would be called in. There was a short pause from the group and then the conversation topic changed. The research-facilitator noticed this and prompted the group again:

$\boldsymbol{R F}$ : So ... are we going to have a curator? ...silence....

CR13: I don't think we need a curator coz sometimes those who decide (shakes head)...someone once said there is no junk in art...let one judge his or her own work CR2: No curating

CR6: Why can't we do it this way...each one has their style, maybe we could all see everyone else's work then help each other to say this is the work to choose...

$\boldsymbol{R F}:$ Is that not the same as curating?

CR10: It's about judging that this isn't art.... 
CR8: It needs to be constructive...

CR6: At the end of the day some people won't submit their work

When the co-researchers reflected on their reaction to this topic, they identified there were concerns about the type of power structures that might be set up with this role. Their experiences of curating were all linked to the oppressive structures they were working in and thus they had reservations.

CR13: We said we didn't want because some of them treat us badly, so we want to do this for ourselves - where the artist is curator

CR12: We need a spokesperson ...the curator needs to understand us, someone who started the journey with us and has walked with us that knows how the journey started

The co-researchers worked through their negative association with this key event role and were able to change their perception of it once the option of having a peer take on the role of curator was presented. Chambers (2006), argues that the marginalised are experts of their reality and thus a social change project can be improved by incorporating more input from the community of interest in the design process. The established event design process is largely reliant on the voice of specialist event designers who are given the task of ideating and developing a suitable event concept based on the client brief (Berridge, 2015). This specialist role can inadvertently set up new power relationships that can further marginalise the community of interest. The participatory event design process does not prescribe the removal of the event designer role, it requires the event designer to approach their role differently by seeking to collaborate with other event design experts who are from the community of interest.

\section{Reversion to Default Power Hierarchies When Challenges Were Encountered}


It is important to also note that the application of participatory approaches comes with its own set of challenges. At the start of the project, the group had decided on the highest level of participatory working which meant that all decisions on the event would be made by the group. At times decision making was not straightforward or quick and some group members would occasionally revert to trying to establish the hierarchical power structures that they were used to encountering.

CR1: I think seriousness should be part of our ways of thinking because I see people joining and not saying anything just like bearer cheques not buying anything CR2: I think there should be a cut off time for participation. As in, I get it that we have lives, but contribution... is necessary and we need to move forward together, so I think perhaps it should be reiterated, so that the work load is balanced because this is an indication of things to come re: the actual event when people now need to actually work. CR1: We are happy but we can't be too patient (responding to CR3), time is money CR4:...(to CR1)... you have to be at least a little bit patient, you're saying that cause you are already in the bus that's why you want to tell the driver that the bus is full, please wait for the others...

CR5: I think that only those who are contributing should be allowed to decide on the event

Mertens (2010) and Leavy (2017) remind us that one of the key assumptions of participatory working is that individuals seek to understand the world in which they live and work based on their personal context, thus developing subjective meanings of their experience. This suggests that we can never assume that every individual involved in a participatory design project will make sense of the experience at the same pace as others and thus the event designer adopting this 
approach must allow for more time for decision making and also apply their diagnostic skills to take time to understand each participant's position as there might be other external factors hampering their engagement.

\section{Outcomes}

The co-researchers started the process fairly reserved and it was important for the research-facilitator to overcome the perception of being an insider-outsider by taking the time to bond with the group. The increasing confidence amongst the co-researchers was also evident as the co-researchers shared how they were feeling at the end of the first evaluation workshop:

CR1: I'm feeling 100\% confident, I have been waiting a long time to have an exhibition where I have been participating, I have been dreaming since school to get the chance to curate.

CR13: confidence has been growing since we started our first meeting to now - but your (research-facilitator) commitment is my confidence - you are constantly working, and we see it and that gives us confidence.

The group have confidently gone on to establish their website and are well into the detailed planning of the event sharing their knowledge and details of friends and colleagues who can help with press, materials supply and marketing.

\section{Skills for Events Management in the Third Sector - Facilitating Participatory Design}

This project highlights a need for the event industry to consider whether certain sectors like the Third Sector will require event designers to apply a different skill set. The field of events management has focused on the development of business-based capabilities and skills. However, having taken part in this participatory project it has become clear that the skills that have been more important are facilitation skills, flexibility and diagnostic skills and as such echo 
Lee's (2008) findings regarding co-creation. In order to set up a framework with authentic participation, every single aspect of the project and decision-making processes has to be handled by the group. The events practitioner who is taking on the role of design-facilitator has to apply strategies that are truly emancipatory and do not manipulate communities of interest (Blackburn, 2000). There is still no clear picture of what a truly emancipatory event would look like, but events professionals would need to take a more cautious approach to designing events with a social mission.

\section{CONCLUSION}

Recent discussions around participation in event studies have focused on the planning process for community festivals, recommending the implementation of inclusive strategies; but there is still debate as to the level of participation that could be effectively applied. The development of critical event studies research creates a platform to explore the opportunities of developing transformational approaches that can meet the social aims guiding the projects without disempowering the communities of interest involved. For events in the Global South, decolonising the event design process will be key to avoid segregating and marginalising important actors in the social structures with whom we are commissioned to work. The participatory design process is not without its challenges, as discussed in this paper. An issue for consideration is whether power can ever be ceded by the event designer, who takes on the role of liaison between communities of interest and funders or donors who have project objectives that must be fulfilled, usually within specific time limits. The current discussions in participatory event planning and in participatory design assume there is a certain level of skill and knowledge required to design and plan an event artefact that results in true transformation. This research project has highlighted that community experts are indeed experts of their operational contexts. 
Furthermore, it has shown that participatory working creates space for the event design expert to collaborate with communities in order to provide solutions to challenges that communities are facing. There is an opportunity, therefore, for event managers to expand their skills so as to be able to develop effective partnerships with the communities they work with, in order to provide a more relevant offer for the Third Sector that can bring about social change. 


\section{REFERENCES}

Arnstein, S. (1969). A ladder of citizen participation. Journal of the American Institute of Planners in the City Reader, 35(4), 216-224.

Berridge, G. (2015). Designing event experiences. In S. J. Page \& J. Connell (Ed), The Routledge handbook of events. (pp.273-288). London: Routledge.

Blackburn, J. (2000). Understanding Paulo Freire: Reflections on the origins, concepts, and possible pitfalls of his educational approach. Community Development Journal, 35(1), 315.

Bladen, C., Kennell, J., Abson, E., \& Wilde, N. (2017). Events management: An introduction. Oxon: Routledge.

Bowdin, G., Allen, J., O’Toole, W., Harris, R., \& McDonnell, I. (2012). Events Management, $3^{\text {rd }}$ Ed. Oxon, Routledge.

Chambers, R. (1994). The origins and practice of participatory rural appraisal. World development, 22(7), 953-969.

Chambers, R. (2006). Transforming power: From zero-sum to win-win? Institute of Development Studies Bulletin, 37(6), 99-110.

Chikukwa, R. (2015) Returning to the early conversations: re-examining missionary and nonmissionary interventions in the development of art in Zimbabwe during the colonial era. In I. Mabasa (Ed), Mawonero / Umbono: Insights on art in Zimbabwe (pp. 9-29). Bielefeld: Kerber Verlag.

Clarke, A., \& Jepson, A. 2011. Power and hegemony within a community festival. International Journal of Event and Festival Management, 2(1) p. 7-19 
Cole, S. (2006). Information and empowerment: The keys to achieving sustainable tourism. Journal of Sustainable Tourism, 14(6), 629-644

Creswell, J. W. (2003). Research design: Qualitative, quantitative and mixed method approaches ( $2^{\text {nd }}$ Ed.) California: Sage Publications

Dagron, A. G. (2009). Playing with fire: Power, participation and communication for development. Development in Practice, 19(4), 453-465

Escobar, A. (1995). Encountering development: The making and unmaking of the Third world. New Jersey: Princeton University Press.

Fanon, F. (1963). The wretched of the earth. New York: Grove Press.

Finkel, R., \& Sang, K. (2016). Participatory research: Case study of a community event. In I. Lamond \& L. Platt (Eds), Critical event studies: Approaches to research. (pp.195-211) London: Springer Nature.

Freire, P. (1996). Pedagogy of the oppressed. London: Penguin Books (Penguin Classics).

Hung, K., Sirakaya-Turk, E., \& Ingram, L J. (2011). Testing the efficacy of an integrated model for community participation. Journal of Travel Research. 50(3), 276-288

Jepson, A., \& Clarke, A., \& Ragsdell, G. (2013). Applying the motivation-opportunity-ability (MOA) model to reveal factors that influence inclusive engagement within local community festivals. International Journal of Event and Festival Management, 4(2), $186-205$

Jepson, A., Clarke, A., \& Ragsdell, G. (2014). Integrating 'self-efficacy’ theory to the Motivation-Opportunity-Ability (MOA) model to reveal factors that influence inclusive engagement within local community festivals. International Journal of Event and Festival Management, 5(3), 219-234. 
Kemmis, S., \& McTaggart, R. (2000). Participatory action research. In N. K. Denzin \& Y. S. Lincoln (Eds.), Handbook of qualitative research, $2^{\text {nd }}$ Edition (pp. 567-607). Thousand Oaks, CA: Sage.

Kesby, M., \& Gwanzura-Ottemoller, F. (2007). Researching sexual health: Two participatory action research projects in Zimbabwe. In S. Kindon, R. Pain, \& M. Kesby (Eds), Participatory action research approaches and methods: Connecting people, participation and place (pp.71-79). Oxford: Routledge

Kindon, S. Pain R., \& Kesby, M. (Eds) (2007). Participatory action research approaches and methods: Connecting people, participation and place. Oxford: Routledge

Krippendorff, K. (2011). Principles of design and a trajectory of artificiality. Journal of Product Innovation Management, 28 (3), 411-418.

Lamond, I., \& Platt, L. (2016). Critical event studies: Approaches to research. London: Springer Nature.

Loomba, A. (2005). Colonialism/postcolonialism (2 ${ }^{\text {nd }}$ Ed.) Oxford: Routledge.

Leavy, P. (2017). Research design: Quantitative, qualitative, mixed methods, arts-based and community-based participatory research approaches. New York: The Guildford Press.

Lee, Y. (2008). Design participation tactics: The challenges and new roles for designers in the co-design process. CoDesign: International Journal of CoCreation in Design and the Arts, 4(1), 31-50.

Lekaota, L. (2015). The importance of rural communities' participation in the management of tourism management: A case study from Lesotho. Worldwide Hospitality and Tourism Themes, 7(5), 453-462. 
Mari, E. (2011). Reducing dependency, towards sustainability: What conditions are necessary for viable creative industries and a sustainable creative sector in Africa? Zimbabwe: National Arts Council.

Mertens, D.M. (2010). Transformative mixed methods research. Qualitative Inquiry, 16(6), 469474.

Mohan, G. (2001). Participatory development. In V. Desai \& R. Potter (Eds.) The Arnold companion to development studies. London, UK: Hodder

Mukanga, F. (2011). Report on Zimbabwe's Art and Culture Framework. Arterial Network and Nhimbe Trust: Zimbabwe

Nelson, K. B. (2009). Enhancing the Attendee's Experience through Creative Design of the Event Environment: Applying Goffman's Dramaturgical Perspective. Journal of Convention \& Event Tourism, 10(2), 120-133.

Olberding, J. C. (2017). Social enterprise and special events: Market-based approaches to mission-driven gatherings. New York: Routledge.

O’Sullivan, D. (2012) Public events, personal leisure. In S. J. Page \& J. Connell (Eds), The Routledge handbook of events. London: Routledge.

Parfitt, T. (2004) The ambiguity of participation: A qualified defence of participatory development. Third World Quarterly, 25(3), 537-555.

Richards, G., Marques, L., \& Mein, K. (2015). Event design: Social perspectives and practices. London: Routledge.

Rojek, C. (2013). Event power: How global events manage and manipulate. London: Sage Publishing.

Said, E. (2003). Orientalism. London: Penguin 
Sanders, E. B. N., \& Stappers, J. P. (2008). Co-creation and the new landscapes of design. CoDesign: International Journal of CoCreation in Design and the Arts, 4(1), 31-50.

Sibanda, D. (2015) Main drivers for the growth and development of sculpture movements in Zimbabwe. In I. Mabasa, I (Ed) Mawonero / Umbono: Insights on art in Zimbabwe (pp31-51). Bielefeld: Kerber Verlag

Simmons, D.G. (1994) Community participation in tourism planning. Tourism Management, 15(2), 98-108

Shone, A., \& Parry, B. (2013) Successful event management: A practical handbook, $4^{\text {th }}$ Ed. Hampshire, Cengage Learning

Smith, L.T. (2012). Decolonizing methodologies: Research and indigenous peoples, $2^{\text {nd }} \mathrm{Ed}$. London: Zed Books Ltd.

Spaaij, R., \& Jeanes, R. (2013) Education for social change? A Freirean critique of sport for development and peace. Physical Education and Sport Pedagogy, 18(4), 442-457.

Taylor, G. (1995). The community approach: Does it really work. Tourism Management, 16(7), 487-489.

Thiong'o, N. W. (1986) Decolonising the mind. London: James Currey

Tosun, C., \& Timothy, D. J. (2003). Arguments for community participation in the tourism development process. The Journal of Tourism Studies, 14(2), 2-15.

Vambe, M. T. (2000). Orality and cultural identities in Zimbabwe. Harare: Mambo Press, Zimbabwe.

VeneKlasen, L., \& Miller, V. (2002). A new weave of power, people and politics: The action guide for advocacy and citizen participation. Oklahoma City: World Neighbors 
Zenenga, P. (2008). Censorship, surveillance and protest theatre in Zimbabwe. Theatre, 38(3), $67-83$. 
Table 1.

Research Participants

\begin{tabular}{lc}
\hline Male & 12 \\
Female & 5 \\
\hline Age & 5 \\
$18-25$ & 6 \\
$26-30$ & 3 \\
$31-35$ & 3 \\
$36-40$ & \\
\hline Average Monthly earnings & 5 \\
Under US\$100 & 11 \\
US\$101-300 & 0 \\
US\$301 -600 & 1 \\
US\$601-900 & \\
\hline
\end{tabular}

